\title{
Afrika Focus - Richtlijnen voor auteurs
}

(I) Talen. Afrika Focus aanvaardt artikels in het Nederlands, Frans en Engels. De taal moet correct zijn wat stijl, woordenschat en spelling betreft.

(2) Voorblad. Elk artikel opent met een voorblad. Dit bevat (a) de naam, affiliatie(s), adres en elektronisch adres van de auteur(s), (b) een abstract van maximum 200 woorden die een samenvatting brengt van de doelstellingen en de resultaten van het artikel, in de taal van het artikel (indien het artikel niet in het Engels is, voorziet de auteur ook een Engelse vertaling van de abstract) (c) maximum vijf trefwoorden in de taal van het artikel én in het Engels, en (d) eventueel 'dankbetuigingen' (deze zullen bij publicatie achteraan het artikel worden geplaatst, na de tekst en vóór de referentielijst).

(3) Opmaak. De tekst wordt als volgt opgemaakt: (a)dubbele interlinie en $12 \mathrm{pt}$ font voor de volledige tekst, inclusief citaten, bibliografische referenties, titels en hoofdingen, (b) marges van $2,5 \mathrm{~cm}$. boven, onder, links en rechts. De hoofdtekst mag maximaal 30 bladzijden (dubbele interlinie) lang zijn, behoudens speciale afspraken met de hoofdredactie of de gastredacteuren. Vermijd het splitsen van woorden op het einde van de zin. Elke nieuwe alinea/paragraaf moet duidelijk aangegeven worden evenals de titels die bovendien zonder nummering geordend worden met een maximum van twee niveaus.

(4) Citaten. Citaten, Latijnse- en anderstalige uitdrukkingen, enz... worden in cursief aangegeven.

(5) Voetnoten. Voetnoten worden tot het strikt noodzakelijke beperkt: auteurs dienen zich steeds af te vragen of wat in een voetnoot staat niet overbodig is. Ze worden doorlopend genummerd en samengebracht aan het einde van het artikel.

(6) Tabellen. De tabellen krijgen een afzonderlijke nummering en moeten een duidelijk opschrift dragen. Met de uitgever worden afspraken gemaakt over de afmetingen en de opmaak van tabellen. Deze afspraken zijn bindend.

(7) Illustraties. Illustraties worden elektronisch en ook apart van de tekst aangeleverd in TIFF-formaat met een minimum resolutie van $300 \mathrm{dpi}$, of in een JPEG-formaat met hoge resolutie, of in PDF-formaat met drukkwaliteit. Afrika Focus aanvaardt geen afbeeldingen in GIF-, MS Word- of MS Excel-formaat. Alle figuren (tekeningen, grafieken, foto's of kaarten) moeten doorlopend genummerd worden. De grafieken die in zwart/wit gedrukt worden, moeten duidelijk interpreteerbaar zijn. Elke illustratie draagt een bondig doch duidelijk onderschrift. Alle elementen van de figuren, letters inbegrepen, moeten groot genoeg zijn om, verkleind, een goede leesbaarheid te behouden.

(8) Referentiesysteem. Afrika Focus volgt in grote lijnen het APA referentiesysteem (http://www.apastyle.org/) voor wat betreft de opname van referenties in de tekst en de opmaak van de referentielijst achteraan het artikel.

(9) Referenties in de tekst. In de tekst dienen de verwijzingen naar de referentielijst als volgt te worden voorgesteld:

a) auteursnaam in kleine letters, gevolgd door een komma en het jaartal van publicatie, eventueel gevolgd door een dubbel punt en de paginareferentie (Janssens, 1975:5-15)

b) indien er twee auteurs zijn: (Janssens \& Peterson, 1975: 5-15)

c) indien er meer dan twee auteurs zijn: (Janssens et al., 1975: 5-15).

(10) Referentielijst. De referentielijst komt achteraan het artikel en vermeldt alle geciteerde werken. De referenties moeten in alfabetische volgorde van de auteurs en, voor éénzelfde auteur (of groep auteurs), in chronologische volgorde, worden opgegeven.

De bibliografische referenties dienen opgesteld te worden als volgt:

- In geval van een artikel uit een tijdschrift:

Naam van de auteur, Voornaam (datum). Titel van het artikel. Titel van het tijdschrift, volume (nummer): pagina's.

- In geval van een artikel uit een boek:

Naam van de auteur, Voornaam (datum). Titel van het artikel. In A. Redacteur (red.), Titel van het boek, pp. $x-x$ ). Uitgaveplaats: Uitgever.

- In geval van een boek:

Naam van de auteur, voornaam (datum). Titel van het boek. Uitgaveplaats: Uitgever, pagina's.

- In geval van een proceedings (congres, symposium, enz...):

Naam van de auteur, Voornaam (datum). Titel van het artikel. In: Titel van de proceedings, pp. $x$-x. Plaats, datum.

(II) Overdrukken. De auteur krijgt twee exemplaren van het tijdschrift en mag twee namen en adressen opgeven van personen aan wie een exemplaar zal worden toegestuurd. Bovendien krijgt de auteur een pdf-bestand van zijn of haar artikel in opgemaakte vorm.

(12) Voorstel van reviewers. De auteurs mogen een lijst opgeven van maximaal 6 personen (verbonden aan onderzoeksinstellingen) die ze geschikt achten als reviewer. De redactie is niet verplicht om deze suggesties te aanvaarden, maar zal anderzijds eventuele verzoeken om uitsluiting van bepaalde reviewers respecteren.

(13) Indiening. Het manuscript dient digitaal, als Worddocument, via e-mail aan het redactiesecretariaat te worden bezorgd. Bij ontvangst krijgt de auteur een bevestiging. 


\section{Afrika Focus - Guidelines for authors}

(I) Languages. Afrika Focus only accepts articles in Dutch, French and English. The language should be correct with regard to style, vocabulary and spelling.

(2) Cover page. Each article opens with a cover page with the following information: (a) the name, affiliation(s), address and electronic address of the author(s), (b) an abstract of no more than 200 words, summarizing the main objectives and the conclusions of the article, in the language of the article (when the article is not written in English, the author should also provide an English translation of the abstract), (c) a maximum of five keywords in the language of the article, as well as in English, and (d) possibly a word of thanks (in print these words of thanks will be put at the end of the article, after the text and before the references).

(3) Layout. The text should be laid out as follows: (a) double-spaced with font 12 throughout, including the citations, bibliographical references, titles and captions, (b) margins of $2.5 \mathrm{~cm}$. on top, at the bottom, left and right. The main text should be no longer than 30 pages (double-spaced), except for special arrangements with the chief or guest editors. Avoid splitting words at the end of the line. Each new paragraph should be clearly indicated, as should the titles. Titles should be ordered without numbering, with a maximum of two levels.

(4) Quotations. Quotations, expressions in Latin or in any other foreign language, etc... should be marked by italics.

(5) Footnotes. Footnotes should be kept to a minimum: authors should check to make sure that a footnote does not give redundant information. Footnotes should be numbered consecutively and typed at the end of the text.

(6) Tables. Tables should be numbered separately and carry clear captions. Arrangements will be made with the publisher regarding the size and layout of the tables. These arrangements are binding.

(7) Figures. Figures should be submitted electronically and separate from the text. The format can be either TIFF, with a minimum resolution of $300 \mathrm{dpi}$, a high-resolution JPEG, or a PDF with printing quality. Afrika Focus does not accept figures in GIF-, MS Word- or MS Excel-format. All figures (drawings, graphs, pictures or maps) should be numbered consecutively. The reader should be able to clearly interpret graphs printed in black-and-white. Each figure should have a brief and clear legend. All aspects of the figures, including letters, should be large enough to still be legible when reduced in size.

(8) References. Afrika Focus largely follows the APA reference system (http://www.apastyle.org/) with regard to references cited in the text and the reference section at the end of the article.

(9) References in the text. References in the text should read:

a) name of the author in lower-case, followed by a comma and the year of publication, possibly followed by a colon and the page reference (Janssens, 1975:5-15)

b) if there are two authors (Janssens \& Peterson, 1975: 5-15)

c) if there are more than two authors (Janssens et al., 1975: 5-15).

(10) Reference list. All text references should be listed at the end of the article, in alphabetical order of the authors and, for the same author (or group of authors), in chronological order.

The bibliographical references should read as follows:

- In case of an article from a journal:

Last name of the author, First name (date). Title of the article. Title of the journal, volume (number): pages.

- In case of an article from a book:

Last name of the author, First name (date). Title of the article. In A. Editor (ed.), Title of the book, pp. $x$-x. Place of publication: Publisher.

- In case of a book:

Last name of the author, First name (date). Title of the book. Place of publication: Publisher, pages.

- In case of proceedings (conference, symposium, etc...):

Last name of the author, First name (date). Title of the article. In: Title of the proceedings, pp. $x$-x. Place, date.

(II) Offprints. Each author receives two copies of the journal and can give two names and addresses of persons who will receive a copy of the journal. Additionally, the author will also receive a final PDF of his/her article.

(12) Suggesting reviewers. Authors can submit a list of up to 6 persons (connected to research institutions) eligible to review their article. The editors are not obliged to comply with these suggestions, but they will respect requests regarding the exclusion of certain reviewers.

(13) Submission. The manuscript should be submitted digitally to the editorial secretariat, as a Word document attached to an email. The author will receive confirmation of the receipt of the manuscript. 


\section{Afrika Focus - Instructions pour auteurs}

(I) Langues. Afrika Focus accepte des articles en néerlandais, français et anglais. La langue doit être utilisée correctement en ce qui concerne le style, le vocabulaire et l'orthographe.

(2) Page de titre. Chaque article sera précédé d'une page de titre qui contiendra (a) le(s) nom(s), l'affiliation/les affiliations, l'adresse, et le courriel d'auteurs,(b) d'un résumé, de maximum 200 mots rédigé dans la langue de l'article, qui résumera les objectifs et les résultats, (si l'article n'est pas en anglais, l'auteur fournira également une traduction en anglais), (c) maximum cinq mots clés dans les deux langues respectives, et (d) en cas de remerciements (ceux-ci seront publiés à la fin de l'article, après le texte mais précédant la liste des références).

(3) Présentation du manuscrit. Le texte intégral en Times New Roman doit être fourni à double interligne. Une police de 12 points sera utilisée pour le texte intégral, y compris les citations, les références bibliographiques, les titres et les entêtes. Les marges sont de $2,5 \mathrm{~cm}$ en haut, et bas de page, à gauche et à droite. Le texte principal ne doit pas excéder 30 pages (double interligne), à moins qu'il en soit convenu autrement avec les Rédacteurs en Chef. Eviter de scinder les mots en fin de phrase. Chaque nouveau paragraphe ou titre est indiqué clairement. Les titres ne sont pas numérotés et en outre limités à deux niveaux.

(4) Citations. L'italique est utilisé pour mettre en évidence les citations, les expressions en latin ou autre langue.

(5) Notes infrapaginales. Les notes infrapaginales sont limitées au stricte minimum: les auteurs doivent se poser la question si ce qui a été intégrer dans la note est vraiment important. La numérotation de celles-ci est continue et elles sont présentées à la fin de l'article.

(6) Tableaux. Les tableaux sont numérotés séparément et pourvus d'une légende. Les dimensions et la mise en page sont à convenir avec l'éditeur. Cet accord est contraignant.

(7) Illustrations. Les illustrations sont fournies électroniquement et séparément, soit en format TIFF avec une résolution de $300 \mathrm{dpi}$, soit en format JPEG à haute résolution, soit en format PDF, qualité d'impression. Afrika Focus n'accepte pas les illustrations fournies en format GIF, Word ou Excel. Toutes les figures (y compris dessins, graphiques, photos ou cartes) doivent être numérotées en continu. Les graphiques imprimés en noir et blanc doivent être lisibles. Chaque illustration est pourvue d'une légende claire et brève. Tous les éléments des figures, lettres inclues, doivent être assez grands afin d'être lisibles après réduction.

(8) Système de refférence. Afrika Focus suit en grandes lignes le système APA (http://www.apastyle.org) pour l'intégration des références dans le texte et la mise en page de la liste des références à la fin de l'article.

(9) Références dans le texte. Dans le texte on réfere à la liste des références de la manière suivante:

a) Le nom de l'auteur en minuscule, suivi d'une virgule, l'année de publication, éventuellement suivie d'un double point et de la page (Janssens, 1975: 5-15);

b) s'il y a deux auteurs: (Janssen \& Peterson, 1975: 5-15)

c) plus de deux auteurs: (Janssen et al., 1975:5-15).

(10) Liste des références. La liste des références vient à la fin de l'article et mentionne toutes les publications citées. Les références sont classées par ordre alphabétique et chronologique en fonction du nom du premier auteur (ou groupe d'auteurs).

Les références bibliographiques suivent les règles suivantes:

- Pour un article dans une revue, on indiquera:

Nom de l'auteur, Prénom (date). Titre de l'article. Titre de la revue, volume (numéro): pages.

- Pour un article dans un livre, on indiquera:

Nom de l'auteur, Prénom (date). Titre de l'article. Dans A. Rédacteur (red.), Titre du livre, pp. x-x. Lieu d'édition: Editeur.

- Pour un livre, on indiquera:

Nom de l'auteur, Prénom (date). Titre du livre. Lieu d'édition: Editeur, pages.

- Pour les actes de colloques (congrès, symposium, etc...), on indiquera:

Nom de l'auteur, Prénom (date). Titre de l'article. Dans: Titre des actes, pp. $x$-x. Lieu, date.

(II) Tirés à part. Deux exemplaires de la revue seront remis à l'auteur. L'auteur peut également communiquer deux adresses auxquelles un exemplaire sera envoyé. En outre, l'auteur reçoit son article en PDF.

(I2) Proposition de lecteurs. Les auteurs peuvent proposer 6 personnes au maximum (attachées à un institut de recherche) qu'ils estiment valables en tant que lecteur. La rédaction n'est pas obligée d'accepter ces suggestions mais respectera en outre la demande d'exclusion de certains lecteurs.

(13) Indication de mise en page. Le manuscrit doit être adressé en format Word, par courriel au secrétariat de rédaction. Les auteurs reçoivent un accusé de réception. 


\section{BLACK (1) Sabel}

\section{AFRICAN BOOKS \& CULTURE}

Verzendboekhandel voor romans, verhalen- en dicht-bundels, literaire en culturele studies, boeken over kunst, film, muziek, dans, percussie, architectuur, mode, etc..

() Levertijd: max. 2 weken voor boeken uit de stocklist (op aanvraag); andere boeken zo snel mogelijk!

(?) Geen verzendkosten voor Nederlandstalige boeken. Bij anderstalige boeken worden alleen de netto-verzendkosten aangerekend!

(0) Eerst krijgt u het boek/de boeken in huis, daarna betaalt u pas!

(0) 10\% korting voor studenten, bibliotheken en documentatiecentra!

(0) 10\% korting wanneer 5 of meer boeken besteld worden!

(?) Extra service: Black Label kan u via de e-mail op de hoogte houden van publicaties op uw vak- of interessegebied m.b.t. Afrika.

$\mathrm{U}$ kunt dit via een mailtje aan ons doorgeven.

Voor informatie, bestellingen of voor het aanvragen van een stocklist, bel, fax, schrijf, mail of surf naar:

\section{BLACK (C) Sabel}

Tel: 03/2360212 / gsm: 0495/677553(I4.00-18.00 uur)

E-mail: info@blacklabel.be

www.blacklabel.be 